community, a lot of compilation work and methodological harmonisations are still needed before global maps of Last Ice Age continent temperatures can be presented in near future.

In conclusion, the workshop served to set up an international agreement for the temporal range of the Last Ice Age time slice and provided a forum for extensive discussion of recently gained paleotemperature data and conflicting views on these new data. The workshop also served as a basis for new collaborative research between paleoclimatologists working on land and in the ocean, and modelers. Following this encouraging start in 1999, the second EPILOG workshop is planned to be held in October 2000 in order to reconcile "Global Ice Sheets and Sea Level during the Last Glacial Maximum" (www.images.cnrsgif.fr/workshops.html).

\section{References}

Braconnot P. Paleoclimate Modelling Intercomparison Project (PMIP). Proceedings of the third PMIP workshop, Canada, 4-8 October 1999, WCRP-111, WMO/TD-No. 1007, 271 (2000).

CLIMAP Project Members. Seasonal reconstruction of the Earth's surface at the last glacial maximum. Geol. Soc. Amer., Map and Chart Series, C36 (1981).

Eglinton T. et al. Alkenone biomarkers gain recognition as molecular paleoceanographic proxies. EOS (submitted).

Farrera I. et al. Clim. Dyn. 15, 823-856 (1999)

Fleming K. et al. Earth Planet. Sci. Lett. 163, 327-342 (1998).

Pinot S. et al. Clim. Dyn. 15, 857-874 (1999).

Rosell-Melé A. et al. EOS 79(33), 393-394 (1998).

\section{RalPh Schneider}

Fachbereich Geowissenschaften, Universität Bremen, Germany

rschneid@uni-bremen.de

\section{EDOUARD BARD}

CEREGE, CNRS, Université d' Aix-Marseille III, Aix-EnProvence, France ebard@cerege.fr

\section{Alan C. Mix}

Oregon State University, Corvallis OR, USA

mix@oce.orst.edu

\title{
Integration of Ice-Core, Marine and Terrestrial Records (INTIMATE): A Core Project of the INQUA Commission on Paleoclimate
}

The abrupt, millennial-scale climatic fluctuations of the Last Glacial Termination are among the most intensivelystudied features of the late Quaternary. High-resolution records of this period are available from the terrestrial, marine and polar ice realms. Careful scrutiny of this collective evidence may well hold the key to understanding complex feedbacks in land-sea-ice interactions, and to establishing the mechanisms behind some of the sub-Milankovitch climatic fluctuations that are so prominent in the Greenland ice-core records. The INTIMATE programme, launched at the XIV th INQUA Congress held in Berlin in 1995, was established to encourage collaboration between members of the ice-core, marine and terrestrial 'communities' in order to synthesise the large number of high-resolution stratigraphical records of the Last Glacial Termination that are now available from the North Atlantic region. Subsidiary aims included establishing procedures for more precise dating and more accurate correlations of regional and / or site data-sets, and testing the notion that the North Atlantic limb of the ocean conveyor was the major driver of abrupt climatic changes in the North Atlantic region during the Last Glacial Termination. The main outcome of this collaborative effort so far has been the formulation of a new stratigraphic scheme for the North Atlantic region: an 'event stratigraphy' for the Last Glacial Termination, based on the stratotype of the GRIP ice-core record (Björck et al., 1998; Walker et al., 1999). This is considered to offer a more satisfactory alternative to conventional stratigraphical procedures for inter-regional data syntheses, as well as for the assessment of the degree of synchroneity of short-term climatic events. The scheme is gradually being adopted by more and more research groups to underpin regional data-syntheses, and to effect more precise inter-regional correlations (Walker et al., in prep.).
The INTIMATE programme is now entering a new phase. Following recommendations made at a workshop held at the $\mathrm{XV}^{\text {th }}$ INQUA Congress in Durban in August 1999, the INTIMATE programme is to enlarge its focus to consider the evidence not only from the North Atlantic region, but also from the South Atlantic and Mediterranean regions. The aims are to compare the timing and magnitude of millennialscale climatic fluctuations during the Last Glacial Termination between these three major regions. The details of how the programme will proceed with this task will be discussed at the next international workshop of INTIMATE, which will be held in Kangerlussuaq, Greenland in August 2000. Participation in the work of INTIMATE is open to any scientist with interests in, and / or data pertinent to, the aims of INTIMATE. Individuals or research groups who have developed detailed paleo-environmental reconstructions for the Last Glacial Termination in the Atlantic region, especially well-dated records suitable for calibration to the calendar time-scale, are encouraged to participate in the programme by contacting the INTIMATE Secretary, Wim Hoek, or the INTIMATE Co-ordinator, John Lowe.

\section{References \\ Biörck et al. 1998, Journal of Quaternary Science 13 283-292. \\ Walker et al. 1999 Quaternary Science Reviews 18, 1143-1150. \\ Walker, et al. (in prep.) Quaternary Science Reviews.}

\section{W.Z. Hoek}

Department of Quaternary Geology and Geomorphology, Vrije Universiteit, Amsterdam, The Netherlands hoew@geo.vu.nl http://www.geo.vu.nl/ quageo/staff/hoew.html http://www.geo.vu.nl/ intimate/ 